\title{
Analisis Kualitas Briket Arang Tempurung Kelapa Dengan Bahan Perekat Tepung Kanji Dan Tepung Sagu Sebagai Bahan Bakar Alternatif
}

\author{
Ardina Ningsih ${ }^{*}$, Ibnu Hajar ${ }^{2}$ \\ $1^{*, 2}$ Politeknik Negeri Bengkalis \\ *Ardinaningsih24@gmail.com
}

\begin{abstract}
This research was conducted to utilize coconut shell waste in the community by processing it into briquettes. The purpose of this study was to determine the quality of coconut shell charcoal briquettes that are good for use as an alternative fuel. Limitation of the problem in this study is starch and sago flour with a composition ratio of 90:10. Pressing pressure used is $2000 \mathrm{~kg} / \mathrm{cm}^{2}$. Drying temperature is $100^{\circ} \mathrm{C}$ using solar heat for 3 days. Carbonization temperature is $500^{\circ} \mathrm{C}$. Coconut shell is $1 \mathrm{~kg}$, the adhesive ratio is $100 \mathrm{grams} / 0.2$ liters of water and does not use a coating. The method used in this study is the method of pyrolysis with the combustion process using a closed furnace and sifting using a sieve with a size of 40-60 mesh. Furthermore, testing the quality of the briquettes are briquette water content (\%), ash briquette content (\%), volatile matters $(\%)$, fixed carbon content (\%), measurement of density $\left.\left(\mathrm{g} / \mathrm{cm}^{2}\right)\right)$, specific gravity $\left(\mathrm{kg} / \mathrm{m}^{3}\right)$, measurement of combustion rate ( $\mathrm{gr} / \mathrm{min})$ and compressive firmness $\left(\mathrm{kg} / \mathrm{cm}^{2}\right)$. The results of testing the quality of coconut shell charcoal briquettes obtained the average value of water content is $3.42 \%$, the average value of ash content is $3.318 \%$, the average value of the vaporizer content is $3.31 \%$, the average value of bound carbon content is $93.37 \%$, the average value of density is $1.55 \mathrm{~g} / \mathrm{cm}^{3}$, the average value of specific gravity is $1.52 \times 10-6 \mathrm{~kg} / \mathrm{m}^{2} . \mathrm{s}^{2}$, the average value of combustion rate is $0.342 \mathrm{~g} / \mathrm{cm}^{2}$, the average compressive strength value is $761.5 \mathrm{~N} / \mathrm{m}^{2}$.
\end{abstract}

Keywords: Biomass, Alternative fuels, Briquettes, Quality, Analysis

\begin{abstract}
Abstrak
Penelitian ini dilakukan untuk memanfaatkan limbah tempurung kelapa yang ada di masyarakat dengan mengolahnya menjadi briket. Tujuan penelitian untuk mengetahui kualitas briket arang tempurung kelapa yang baik untuk digunakan sebagai bahan bakar alternatif. Pembatasan masalah dalam penelitian ini yaitu tepung kanji dan tepung sagu dengan perbandingan komposisi 90:10. Tekanan pengepresan yang digunakan yaitu 2000 $\mathrm{kg} / \mathrm{cm}^{2}$. Suhu pengeringan yaitu $100^{\circ} \mathrm{C}$ menggunakan panas matahari selama 3 hari. Suhu karbonisasi adalah $500^{\circ} \mathrm{C}$. Tempurung kelapa yaitu $1 \mathrm{~kg}$, perbandingan perekat adalah 100 gram $/ 0,2$ liter air dan tidak menggunakan pelapis. Metode yang digunakan dalam penelitian ini adalah metode pirolisis dengan proses pembakaran menggunakan tungku pembakaran tertutup dan pengayakan menggunakan ayakan dengan ukuran 40-60 mesh. Selanjutnya pengujian kualitas briket yaitu kadar air briket (\%), kadar abu briket (\%), kadar zat menguap (volatile matters) (\%), kadar karbon terikat (fixed carbon) (\%), pengukuran kerapatan (density) $\left(\mathrm{g} / \mathrm{cm}^{2}\right)$, berat jenis $\left(\mathrm{kg} / \mathrm{m}^{3}\right)$, pengukuran laju pembakaran $(\mathrm{gr} / \mathrm{menit})$ dan keteguhan tekan $\left(\mathrm{kg} / \mathrm{cm}^{2}\right)$. Hasil pengujian kualitas briket arang tempurung kelapa didapatkan nilai rata-rata kadar air adalah 3,42\%, nilai ratarata kadar abu adalah 3,318 \%, nilai rata-rata kadar zat menguap adalah 3,31\%, nilai rata-rata kadar karbon terikat adalah $93,37 \%$, nilai rata-rata kerapatan adalah $1,55 \mathrm{~g} / \mathrm{cm}^{3}$, nilai rata-rata berat jenis adalah $1,52 \times 10^{-6}$ $\mathrm{kg} / \mathrm{m}^{2} \cdot \mathrm{s}^{2}$, nilai rata-rata laju pembakaran adalah $0,342 \mathrm{~g} / \mathrm{cm}^{2}$, nilai rata-rata keteguhan tekan adalah $761,5 \mathrm{~N} / \mathrm{m}^{2}$.
\end{abstract}

Kata kunci: Biomassa, Bahan bakar alternatif, Briket, Kualitas, Analisis.

\section{Pendahuluan}

Tempurung kelapa merupakan salah satu biomassa yang ketersediaannya melimpah di Indonesia khususnya di daerah Bantan Air, Kec. Bantan, Kabupaten Bengkalis. Masyarakat biasanya mengambil kelapa untuk diambil santan kelapa yang kemudian digunakan sebagai bahan memasak. Namun, batok kelapa biasanya tidak dimanfaatkan lagi dan terbuang begitu saja sehingga menimbulkan penumpukan limbah batok tempurung kelapa. Adapun beberapa keluarga di desa tersebut sudah mulai 
memanfaatkan limbah batok kelapa untuk dibakar secara pirolisis untuk menghasilkan arang batok kelapa maupun asap cair.

Mengingat kebutuhan akan adanya bahan bakar setiap tahunnya terus mengalami peningkatan dan perlu adanya antisipasi akan ketersediaan sumber energi yang semakin menipis sementara harga bahan bakar minyak meningkat. Kerugian penggunaan bahan bakar fosil ini selain merusak lingkungan, juga tidak terbarukan (nonrenewable) dan tidak berkelanjutan (unsustainable) [1].

Perbedaan komposisi campuran pada pembuatan briket sabut dan tempurung kelapa memberikan pengaruh terhadap kadar air, kadar abu, kadar zat terbang (volattile matters), kadar karbon padat (fixed carbon), dan nilai kalor, Penambahan konsentrasi tempurung kelapa akan menurunkan kadar air, kadar abu, kadar zat terbang (volattile matters) dan akan menaikan kadar karbon padat dan nilai kalor, komposisi yang paling optimal pada briket campuran sabut dan tempurung kelapa yaitu pada komposisi Sabut 50\% : tempurung $50 \%$ karena menghasilkan nilai kalor tertinggi sebesar $6211 \mathrm{kal} / \mathrm{g}$.

Efisiensi pembakaran dapat diketahui dengan melakukan uji pembakaran dengan metode WBT (Water Boiling Test), Dengan menggunakan bahan bakar briket campuran sabut dan tempurung kelapa dengan komposisi 50\% : 50\% didapatkan nilai efisiensi pembakaran sebesar $9,861 \%$. Nilai efisiensi yang didapat kurang baik dikarenakan dimensi kompor gasifikasi tidak sesuai dengan jumlah bahan bakar yang digunakan yang menyebabkan kurang optimalnya transfer panas dari bahan bakar menuju panci [7].

Mengenai kajian ekonomis industri briket arang tempurung kelapa pembuatan arang briket ini belum banyak yang melakukannya, padahal potensi bahan baku dan potensi pasar cukup besar. Dari aspek teknologi, pengolahan arang briket relatif masih sederhana dan dapat dilaksanakan oleh usaha-usaha skala kecil dan menengah. Keterbatasan modal, akses terhadap informasi pasar dan pasar yang terbatas serta kualitas yang belum memenuhi persyaratan, merupakan kendala dan masalah dalam pengembangan usaha industri pengolahan arang briket. Untuk memproduksi arang briket menggunakan peralatan mesin hydrolic press dengan kapasitas produksi per mesin adalah 24, 3 ton perbulan untuk jenis produk coin dan 18,2 ton perbulan untuk jenis produk cube. Selain itu diperlukan mixer dan pengering, klin pembakaran dan bengkel kerja [6].

Proyek industri arang briket sangat layak yaitu menghasilkan NPV= 5.420.744 yang berarti bahwa selama 5 tahun ke depan, proyek tersebut akan menghasilkan Nilai Bersih Sekarang (NPV) sebesar Rp 5.420.744.000,-. Nilai tersebut merupakan nilai perhitungan Internal Rate of Return di atas $100 \%$ yang berarti jika tingkat suku bunga mencapai $100 \%$ per tahun, proyek ini masih mampu menutupi tingkat suku bunga tersebut. Demikian juga halnya jika harga jual lebih rendah $10 \%$ dari perkiraan atau biaya mengalami peningkatan $10 \%$ di atas perkiraan, maka proyek ini masih sangat layak [6].

\subsection{Briket}

Briket adalah suatu bahan berupa serbuk potongan-potongan kecil yang dipadatkan dengan menggunakan mesin press dengan dicampur bahan perekat sehingga menjadi bentuk solid. Perubahan ukuran material tersebut dilakukan melalui proses penggumpalan dengan penekanan dan penambahan atau tanpa penambahan bahan pengikat. Briket arang dibuat dengan mencampurkan bahan-bahan yang memiliki nilai karbon tinggi dan dengan memampatkannya pada tekanan tertentu serta memanaskan pada suhu tertentu sehingga kadar airnya bisa ditekan seminimum mungkin sehingga dihasilkan bahan bakar yang memiliki densitas yang tinggi, nilai kalor yang tinggi serta asap buangan yang minimum [3] 


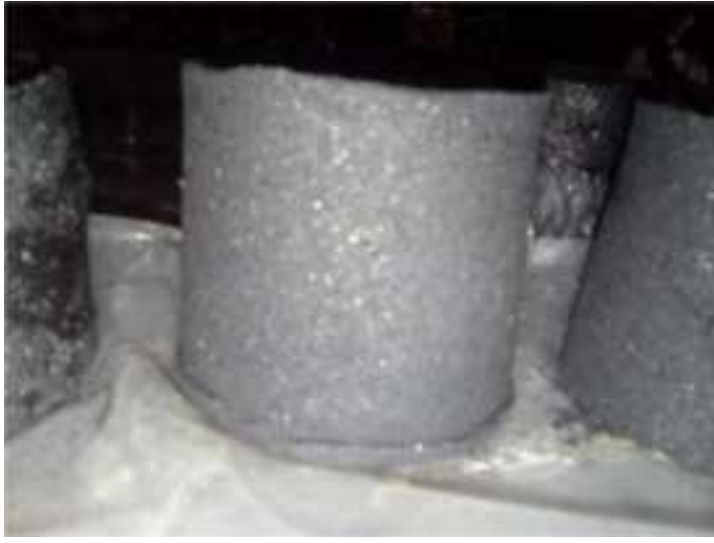

Gambar 1. Briket arang tempurung kelapa Sumber: hasil produk penelitian

\subsection{Macam-macam perekat briket}

Faktor-faktor yang perlu diperhatikan di dalam pembuatan briket antara lain adalah [2]:

a. Bahan Baku

Briket dapat dibuat dari bermacammacam bahan baku, seperti ampas tebu, sekam padi, serbuk gergaji, dll. Bahan utama yang harus terdapat di dalam bahan baku adalah selulosa. Semakin tinggi kandungan selulosa semakin baik kualitas briket, briket yang mengandung zat terbang yang terlalu tinggi cenderung mengeluarkan asap dan bau tidak sedap. Untuk merekatkan partikel-partikel zat dalam bahan baku pada proses pembriketan maka diperlukan zat perekat sehingga dihasilkan briket yang kompak. Berdasarkan fungsi dari perekat dan kualitas perekat itu sendiri, pemilihan bahan perekat dapat dibagi sebagai berikut [5]:

1) Berdasarkan sifat atau bahan baku perekatan briket

Adapun karakteristik bahan baku perekatan untuk pembuatan briket adalah sebagai berikut:

a. Memiliki gaya kohesi yang baik bila dicampur dengan semikokas atau

batubara.

b. Mudah terbakar dan tidak berasap.

c. Mudah didapat dalam jumlah banyak dan murah harganya.

d. Tidak mengeluarkan bau, tidak beracun dan tidak berbahaya.
2) Berdasarkan jenis

Jenis bahan baku yang umum dipakai sebagai pengikat untuk pembuatan briket yaitu:

a. Pengikat Anorganik

Pengikat anorganik dapat menjaga ketahanan briket selama proses pembakaran sehingga dasar permeabilitas bahan bakar tidak terganggu. Pengikat anorganik ini mempunyai kelemahan yaitu adanya tambahan abu yang berasal dari bahan pengikat sehingga dapat menghambat pembakaran dan menurunkan nilai kalor. Contoh dari pengikat anorganik antara lain semen, lempung (tanah liat), natrium silikat [4].

b. Pengikat Organik

Pengikat organik menghasilkan abu yang relatif sedikit setelah pembakaran briket dan umumnya merupakan bahan perekat yang efektif. Contoh dari pengikat organik diantaranya kanji, tar, aspal, amilum, molase dan parafin. Adapun bahan perekat organik yang umumnya digunakan dalam pembuatan briket adalah tepung tapioka dan sagu aren.

1. Tepung Tapioka

Dalam pembuatan biobriket diperlukan perekat ataupun pengikat yang berfungsi untuk merekatkan partikelpartikel zat dalam bahan baku (bioarang) pada proses pembuatan briket. Tepung tapioka termasuk merupakan salah satu jenis bahan perekat organik dan umumnya merupakan bahan perekat yang efektif. Dipilihnya perekat tepung tapioka ini dikarenakan harganya murah serta mudah didapat.

\section{Sagu Aren}

Sagu Aren merupakan salah satu pengikat organik selain tepung tapioka, sagu aren memiliki kadar karbohidrat cukup tinggi dan ketersediaannya cukup melimpah khususnya didaerah yang memiliki usaha perkebunan aren. Sebagai sumber karbohidrat, sagu aren juga memiliki pati dari amilosa dan amilopektin yang menjadikannya mampu mengikat karbon-karbon dalam briket arang seperti halnya tapioka [11]. 


\subsection{Parameter kualitas briket}

Parameter pengujian kualitas briket sesuai standar (SNI NO. 01/6235/2000) adalah sebagai berikut [10]:

1. Kadar air briket

Persamaan menghitung kadar air :

Kadar air $(\%)=\frac{a-b}{b} \times 100 \%$

Dimana :

$\mathrm{a}=$ Massa sampel awal dalam keadaan basah ( gram )

$\mathrm{b}=$ Massa sampel hasil penyusutan dalam keadaan kering ( gram )

\section{Kadar abu briket}

Persamaan menghitung kadar abu:

Kadar abu (\%) $=\frac{b}{a} x 100 \%$

Dimana :

$\mathrm{a}=$ Massa sampel awal (gram)

$\mathrm{b}=$ Massa abu total (gram)

\section{Kadar zat menguap (Volatile matters)}

Persamaan kadar zat menguap[8]:

Kadar zat menguap $(\%)=\frac{(a-b)}{a} \times 100 \%$

Dimana:

$\mathrm{a}=$ Massa sampel sebelum pemanasan (gram)

$\mathrm{b}=$ Massa sampel setelah pemanasan (gram)

\section{Kadar karbon terikat (Fixed carbon)} Persamaan kadar karbon:

Kadar karbon $(\%)=100 \%-(\%$ zat menguap $+\% \quad \% \quad$ abu)

\section{Pengukuran kerapatan (Density)}

Penentuan kerapatan briket yaitu dengan cara menimbang briket yang sudah dikeringkan, kemudian dihitung volume briket sesuai dengan bentuknya, dalam penelitian ini volume tabung, setelah itu dihitung kerapatannya [5].

Perhitungan kerapatan:

Kerapatan $=\frac{G}{V}$

Dimana : $\mathrm{K}=\operatorname{Kerapatan}\left(\mathrm{g} / \mathrm{cm}^{3}\right), \mathrm{G}=$ Bobot kering $(\mathrm{g}), \mathrm{V}=$ volume $\left(\mathrm{cm}^{3}\right)$. Volume briket didapatkan dari $V=\frac{1}{4} \pi d^{2} t$ dimana $\mathrm{d}$ dan $\mathrm{t}$ menyatakan diameter dan tinggi briket.

\section{Pengukuran berat jenis}

Berat suatu benda dipengaruhi oleh massa benda dan gravitasi yang mempengaruhinya. Berat jenis dirumuskan:

Berat jenis $=\frac{\text { massa } . \text { percepatan (gravitas })}{\text { volume }}$ $\left(\mathrm{Kg} / \mathrm{m} \cdot \mathrm{s}^{2}\right)$

Percepatan gravitasi $=9,81 \mathrm{~m} / \mathrm{s}^{2}$

\section{Perhitungan laju pembakaran}

Laju pembakaran briket ditentukan dari berapa berat briket yang terbakar selama periode waktu tertentu. Briket yang akan diuji laju pembakarannya dibakar di atas nyala api, waktu pembakaran dihitung dari awal briket mulai terbakar sampai bara api briket mati. Sisa pembakaran briket ditimbang dengan neraca analitik [5].

Perhitungan laju pembakaran:

Laju pembakaran $(\mathrm{g} / \mathrm{menit})=\frac{W 1-W 2}{t}$

Dimana, $\mathrm{W} 1$ = berat sebelum pembakaran $(\mathrm{g}), \mathrm{W} 2=$ berat setelah pembakaran $(\mathrm{g}), \mathrm{t}=$ waktu pembakaran

\section{Kuat tekan}

Tekanan didefinisikan sebagai gaya tekan yang bekerja pada satu satuan luas permukaan yang mengalami gaya tekan. Simbol tekanan adalah P. Jadi, bila sebuah gaya sebesar $\mathrm{F}$ bekerja pada sebuah bidang A (luas), maka besarnya tekanan adalah :

$\mathrm{P}=\frac{F}{A}$ 
Keterangan :

$\mathrm{P}=$ Kuat tekan bahan $\left(\mathrm{N} / \mathrm{m}^{2}\right.$ atau $\left.\mathrm{kg} / \mathrm{cm}^{2}\right)$

$\mathrm{F}=$ Beban tekan maksimum (gaya tekan)

( $\mathrm{N}$ atau $\mathrm{kg}$ )

$\mathrm{A}=$ Luas bidang bahan $\left(\mathrm{m}^{2}\right.$ atau $\left.\mathrm{cm}^{2}\right)$

Pengukuran kuat tekan dapat dilakukan dengan menggunakan metode uji tekan (press test) sebagai berikut:

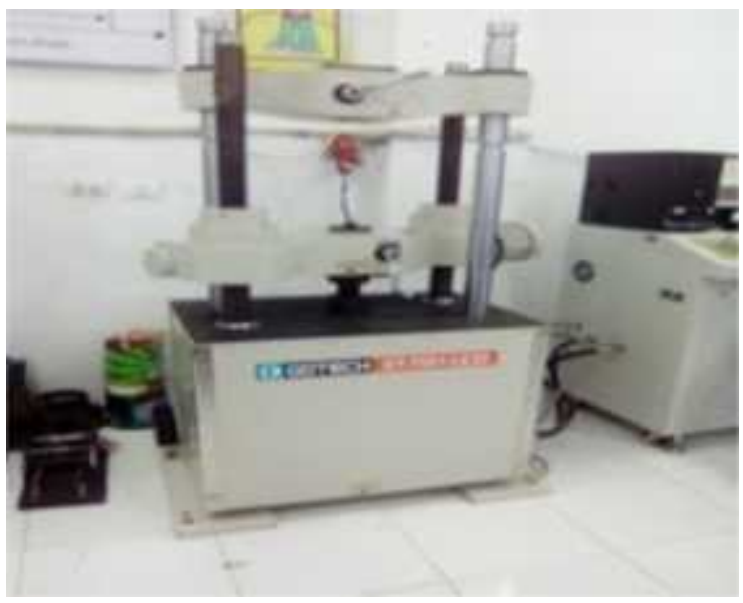

Gambar 2. Alat uji tekan

Uji tekan adalah suatu alat uji mekanik yang berguna untuk mengukur dan mengetahui kekuatan benda terhadap gaya tekan. Uji tekan ini memiliki kinerja yang bagus dan berkualitas untuk mengetahui kekuatan benda. Pada umumnya uji tekan ini digunakan pada logam yang bersifat getas, karena alat uji tekan ini memiliki titik hancur yang terlihat jelas disaat melakukan pengujian benda tersebut.

Dalam metode ini material yang digunakan memiliki volume yang tebal. Cara menggunakannya, material tersebut diletakkan pada bagian lower plate pada mesin, kemudian Universal Testing Machine (UTM) akan memberi gaya tekan pada material tersebut. Setelah material ditekan. Parameter data pada monitor akan menampilkan hasil dari proses pengujian tersebut. Kemudian hasilnya dapat dibandingkan antara material sebelum dan sesudah diuji [12].
2. Metodologi Penelitian
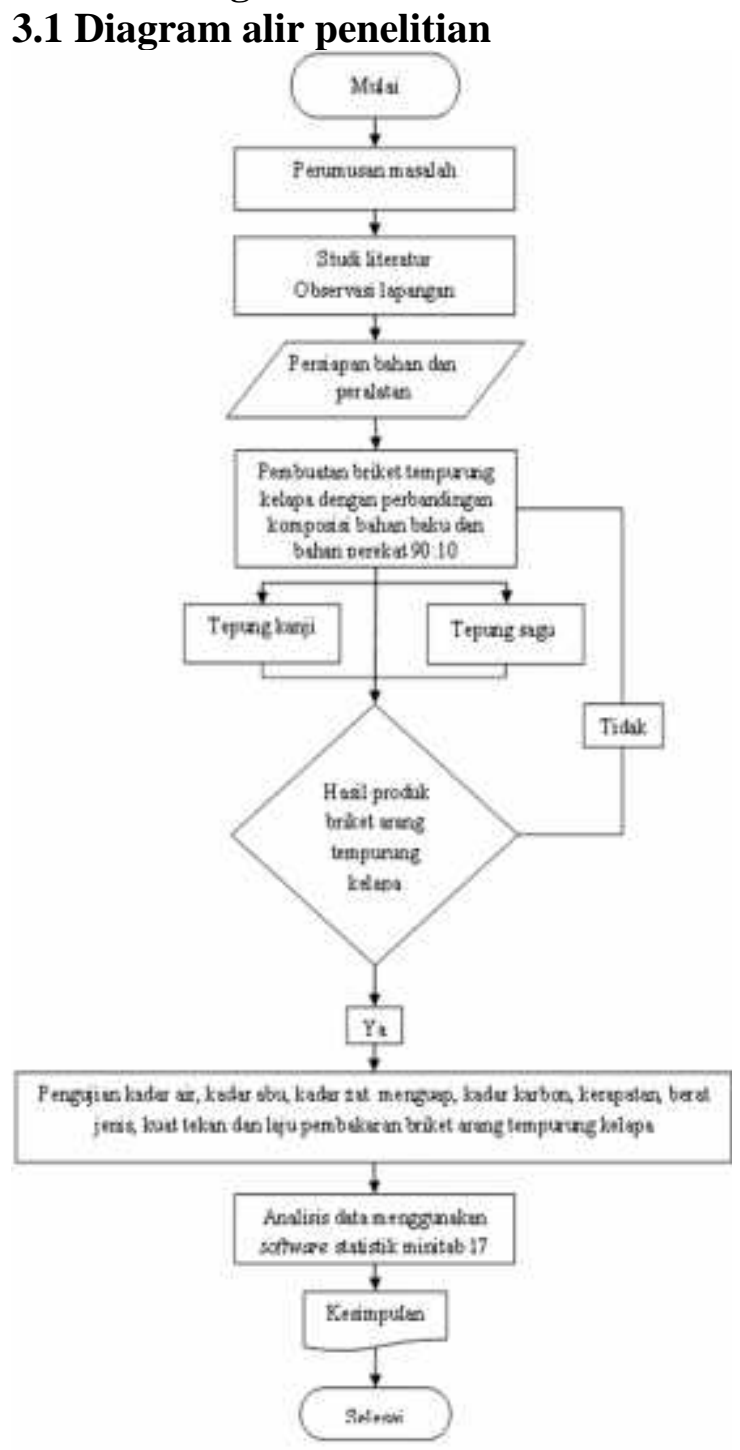

Gambar 2. Alat uji tekan

\subsection{Alat yang digunakan}

Penelitian ini menggunakan beberapa alat dan bahan sebagai berikut:

1. Timbangan digital

2. Pipa PVC

3. Dongkrak hidrolik

4. Termometer infrared

5. Ayakan ukuran 40-60 mesh

6. Lesung batu

7. Kompor gas

8. Stopwatch

\subsection{Bahan}

Bahan baku yang digunakan dalam pembuatan briket arang pada penelitian ini yaitu tempurung kelapa dengan bahan perekat yang digunakan yaitu tepung kanji dan tepung sagu. 


\section{Model Alat Pembuat Briket}

\subsubsection{Alat Pencetak}

Dalam penelitian ini model alat pencetak briket tempurung kelapa yang digunakan adalah alat pencetak sederhana menggunakan dongkrak hidrolik dengan kapasitas 2 ton dan mengggunakan cetakan dari pipa PVC dengan ukuran diameter 5 $\mathrm{cm}$ dan tinggi $5 \mathrm{~cm}$ berbentuk silinder tanpa lubang. Model alat pencetak dapat dilihat pada gambar berikut:

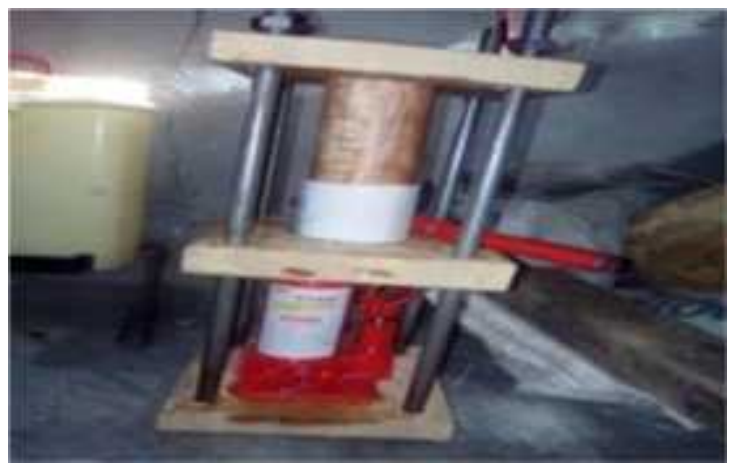

Gambar 3. Alat pencetak briket sederhana

\subsubsection{Alat pirolisis}

Alat pirolisis yang digunakan dalam penelitian ini adalah tungku pembakaran. Tungku dibagi atas 3 bagian yaitu bagian bawah untuk memulai proses pembakaran, bagian tengah, dan bagian atas sebagai penutup dan cerobong asap.

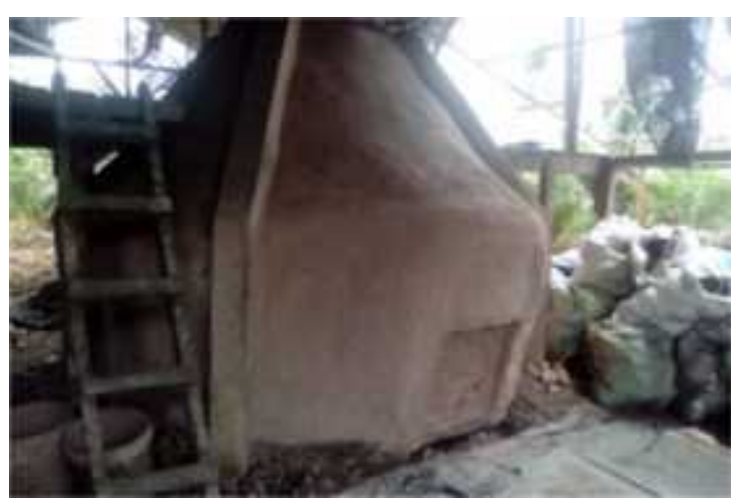

Gambar 4. Tungku pembakaran

\section{Hasil dan Pembahasan}

Berdasarkan pengolahan data statistik menggunakan minitab 17 didapatkan hasil pengujian kualitas briket arang tempurung kelapa sebagai berikut:

Tabel 4.1 Hasil pengujian kualitas briket arang tempurung kelapa

\begin{tabular}{|c|c|c|c|c|c|c|c|c|}
\hline \multicolumn{9}{|c|}{ 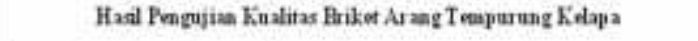 } \\
\hline No & $\begin{array}{l}\text { E.uler } \\
\text { et } \\
09\end{array}$ & $\begin{array}{l}\text { Tuater } \\
\text { dus } \\
(6)\end{array}$ & 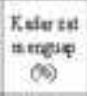 & $\begin{array}{l}\text { Rusut } \\
\text { kathson } \\
(0)\end{array}$ & $\begin{array}{l}\text { Ketapten } \\
\text { (elat) }\end{array}$ & $\begin{array}{l}\text { Bend jeta } \\
\text { (Kogen h) }\end{array}$ & 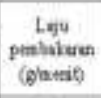 & $\begin{array}{l}\text { Kuet } \\
\text { seves } \\
\text { bdha } \\
\text { Ornt }\end{array}$ \\
\hline 1 & 4,76 & 3,6 & 4,54 & 91,83 & 1.97 & $1.05 \times 10^{2}$ & 8,2 & 525 \\
\hline 2 & 3,5 & 3,44 & 3,45 & 93,11 & 1,43 & $1 / \mathrm{m} \times 10^{\mathrm{S}}$ & 0,32 & 700 \\
\hline 3 & $30 \mathrm{~s}$ & 259 & 2,99 & 93,42 & 165 & $162 \times 10^{2}$ & 037 & 820 \\
\hline 4 & 4 & 3.2 & 3,35 & 92,95 & 1,53 & $1,30 \times 10^{2}$ & 0.34 & 750 \\
\hline 3 & 3,16 & 190 & 306 & $93,3 t$ & 1.21 & $1,53 \times 10^{6}$ & 0.36 & 760 \\
\hline 1 & 22 & $3 \pi 1$ & 2,76 & 93,93 & 1,79 & $150 \times 10^{2}$ & 0,4 & 850 \\
\hline 7 & 26 & 3,99 & 2.57 & 94,34 & 1,92 & $1.89 \times 10^{2}$ & 0.42 & 945 \\
\hline 3 & 3,42 & 3,31 & 3,31 & 9338 & 1,48 & $1, A \times 10^{\circ}$ & 0.33 & 730 \\
\hline 9 & 3,13 & 3,03 & 3,23 & 93,94 & 1,63 & $160 \times 10^{7}$ & 0.36 & 300 \\
\hline 10 & 3,54 & 3,32 & 3,52 & 92,96 & 1,39 & $137 \times 10^{4}$ & $0.3 t$ & 625 \\
\hline $\begin{array}{l}\text { Ros } \\
\text { tuth }\end{array}$ & 200 & 1311 & 3.303 & 9,374 & 1,35 & $1,32 \times 10^{6}$ & 0,34 & 761,3 \\
\hline
\end{tabular}

Data hasil pengujian kemudian dibandingkan dengan standar (SNI NO. 01/6235/2000) sesuai Tabel 4.2 berikut:

Tabel 4.2 Standar briket arang [9]

\begin{tabular}{|c|c|c|c|c|}
\hline Sifte rug tolin! & Jepurz & Ingais & Amrǚa & $35101.623 \times 2000$ \\
\hline Kadurat (\%) & 6.8 & 36 & 62 & $<8$ \\
\hline Kadre dou(N) & 3.6 & 59 & 83 & $<8$ \\
\hline $\begin{array}{l}\text { Kastezanengep } \\
\text { (8) }\end{array}$ & 1130 & 16.4 & 19.28 & $<15$ \\
\hline Kadeksuboe( $(\%)$ & 60.20 & 733 & 60 & $2 \pi$ \\
\hline Kerputen(fen $\left.{ }^{3}\right)$ & $10-12$ & 0.46 & 1 & 20.44 \\
\hline $\begin{array}{l}\text { Kenteghan tére } \\
\text { (gan2) }\end{array}$ & 60.65 & 127 & 62 & . \\
\hline Hin kdar icalid & 6000.7000 & 7200 & 6230 & 5000 \\
\hline
\end{tabular}

Peta kendali X-bar menunjukkan hasil pengendalian kualitas briket arang tempurung kelapa dengan menggunakan bahan perekat tepung kanji dan tepung sagu dengan nilai UCL yaitu 443, nilai LCL yaitu 1954 dengan nilai X-bar yaitu 123,8. Dari hasil menunjukkan bahwa proses terkendali dengan baik. Peta kendali menunjukkan bahwa garis berada pada rentang kualitas briket atau garis tidak melewati batas kendali mengartikan bahwa proses baik. 


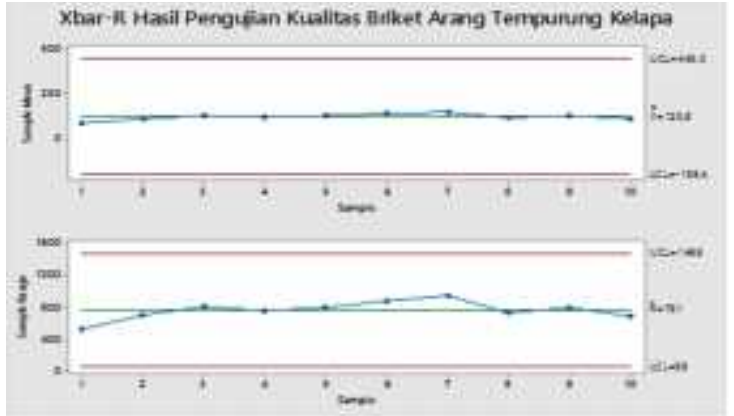

Gambar 5. Peta kendali hasil pengujian kualitas briket arang tempurung kelapa

Gambar 5 merupakan grafik peta kendali X-bar yang menunjukkan hasil pengujian kualitas briket arang tempurung kelapa yang menjelaskan Peta X-bar apakah perubahan-perubahan telah terjadi dalam ukuran titik pusat (control tendency) atau rata-rata dari suatu proses pengukuran tersebut. Peta $\mathrm{R}$ menjelaskan perubahanperubahan yang telah terjadi dalam ukuran variasi, dengan demikian berkaitan dengan perubahan produk yang dihasilkan dalam suatu proses. Nilai UCL (Upper control limits) menunjukkan nilai batasan kendali maksimum sedangkan nilai LCL (Lower control limits) menunjukkan nilai batasan kendali minimum dari suatu proses.

Selanjutnya, dilakukan pengendalian proses yang dalam hal ini artinya apabila proses telah berada dibawah pengendalian statistik maka perlu menentukan kapabilitas proses, yang ditentukan dengan menggunakan ukuran indeks kapabilitas proses (Capability process) dan indeks performansi Kane (Capability process cane/CPK) serta memiliki standar deviasi. Apabila proses berada pada batas pengendali statistik dengan peta pengendali normal dan rata-rata proses terpusat pada target maka kemampuan proses dapat diukur dengan melihat kriteria-kriteria penilaian sebagai berikut:

1. Jika cp > 1,33 maka proses masih baik (capable)

2. Jika cp $<1$ maka proses tidak baik (not capable)

3. Jika $1<\mathrm{cp}<1,33$ maka proses memerlukan kendali
Indeks performansi Kane (CPK) merefleksikan kedekatan nilai rata-rata dari proses sekarang terhadap salah satu batas spesifikasi atas (USL) dan batas spesifikasi bawah (LSL). Kriteria-kriteria penilaian untuk indeks performansi Kane (CPK) adalah sebagai berikut:

1. Jika nilai cpk $>1$ maka performansi masih baik (capable)

2. Jika nilai cpk $<1$ maka performansi tidak baik (not capable)

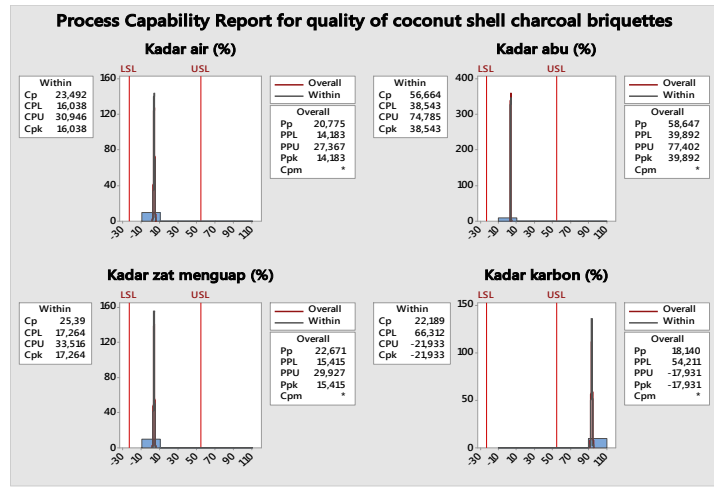

Gambar 6. Kapabilitas proses

Gambar 6 menunjukkan nilai kapabilitas proses CPK pada kadar air, kadar abu, kadar zat menguap, dan kadar karbon telah memenuhi standar kualitas berdasarkan kriteria penilaian kualitas briket.

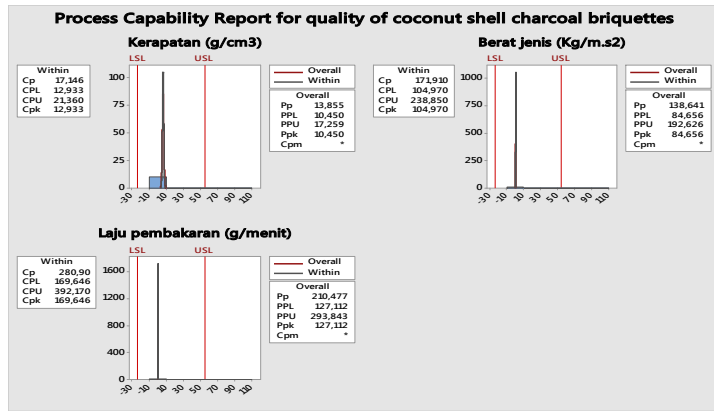

Gambar 7. Kapabilitas proses

Gambar 7 menunjukkan nilai kapabilitas proses pada kerapatan, berat jenis, dan laju pembakaran dari briket arang tempurung kelapa. Nilai telah memenuhi standar kualitas briket sesuai batasan LSL dan USL yang tercatat pada gambar 4.3 diatas. 


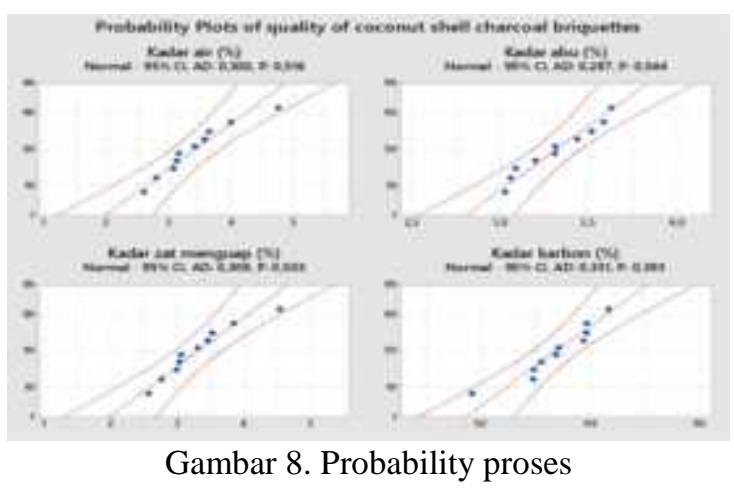

Gambar 8 menunjukkan nilai probability kadar air, kadar abu, kadar zat menguap, dan kadar karbon. Nilai Anderson darling (AD) pada kadar air yaitu 0,300 , kadar abu yaitu 0,287, kadar zat menguap yaitu 0,309 dan kadar karbon yaitu 0,351 . Sedangkan nilai $P$-value pada kadar air yaitu 0,516, kadar abu yaitu 0,544 , kadar zat menguap yaitu 0,503 dan kadar karbon 0,393. Nilai berada pada batas kenormalan data menunjukkan data proses normal dan sesuai kriteria.

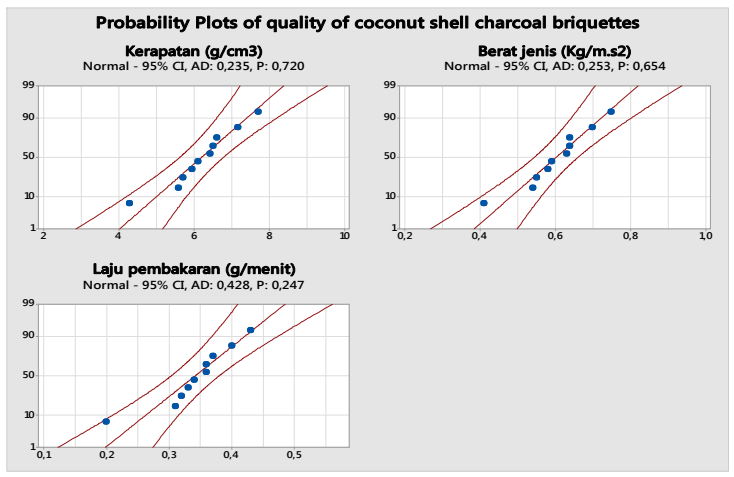

Gambar 9. Probability proses

Gambar 9 menunjukkan nilai probability pada kerapatan, berat jenis, dan laju pembakaran briket arang tempurung kelapa. Nilai berada pada batas kenormalan data menunjukkan data proses normal dan sesuai kriteria dengan nilai Anderson darling (AD) untuk kerapatan yaitu 0,235 , berat jenis yaitu 0,253 dan laju pembakaran yaitu 0,429 sedangkan nilai $P$ value yang ditunjukkan yaitu kerapatan sebesar 0,720 , berat jenis yaitu 0,654 dan laju pembakaran yaitu 0,247

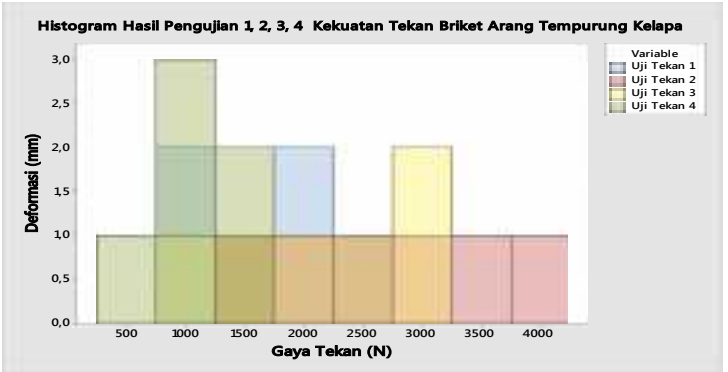

Gambar 10. Histogram kekuatan tekan briket arang tempurung kelapa

Gambar 10 menunjukkan histogram hasil pengujian kekuatan tekan briket arang tempurung kelapa dengan nilai deformasi (Perubahan bentuk) dengan nilai maksimum yaitu 3,0 mm dengan rentang tekanan antara 500-4000 N.

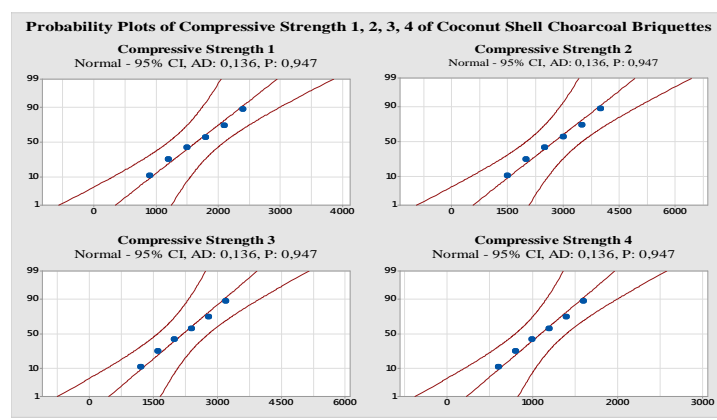

Gambar 11. Probability plot hasil uji tekan 1, 2, 3, dan 4

Gambar 11 menunjukkan nilai probability pada hasil uji tekan 1, 2, 3, dan 4. Berdasarkan metode Anderson Darling (AD) didapatkan nilai kenormalan data dari masing-masing pengujian yaitu 0,136 dengan nilai P-value yaitu 0,947. Berdasarkan Gambar 11 nilai probability dari masing-masing hasil pengujian tekan yaitu pada hasil uji tekan 1 menunjukkan data terdistribusi normal dengan nilai uji kenormalan data menurut metode Anderson Darling $(A D)$ yaitu 0,136 dan nilai $P$ yaitu 0,947 . Hasil pengujian dari masing-masing sampel pengujian 1, 2, 3, dan 4 menunjukkan nilai $A D$ dan nilai $P$ yang sama. Hal ini bisa diartikan bahwa nilai kenormalan data dan pengendalian prosesnya sama dengan rentang nilai probability antara 1000-3500. Nilai proses menggunakan tingkat kepercayaan 95\% sedangkan hasil proses menunjukkan presentase sekitar 93,37\%. Itu artinya data 
mendekati nilai kepercayaan yang digunakan meskipun tidak benar-benar 95\%. Namun data proses bisa dikatakan baik (capable)

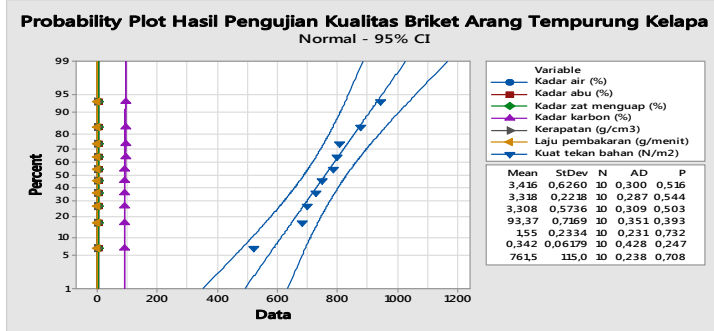

Gambar 12. Grafik Probability plot kualitas briket arang tempurung kelapa

Gambar 12 menunjukkan nilai probability plot dari keseluruhan variabel pengujian kualitas briket arang tempurung kelapa dimana nilai P-value harus lebih besar dari 0,05. Nilai menunjukkan bahwa dari masing-masing variabel pengujian mempunyai nilai $\mathrm{P}$ yang lebih besar dari $\alpha$ besar dari 0,05. Hal tersebut mengartikan bahwa data terdistribusi normal atau proses masih baik (capable). Berdasarkan Gambar 12 nilai mean atau nilai rata-rata dari masing-masing variabel menunjukkan nilai mean kadar air sebesar 3,416\%. Nilai tersebut jika dibandingkan dengan nilai standar kualitas kadar air menurut standar (SNI NO. 01/6235/2000) yang menetapkan standar maksimal kadar air yaitu $8 \%$ bisa diartikan bahwa untuk nilai kadar air pada briket arang tempurung kelapa telah memenuhi standar dengan nilai penyebaran data atau standar deviasi yaitu 0,6. Nilai $\mathrm{N}$ menunjukkan jumlah pengambilan sampel dari masing-masing variabel pengukuran. Metode uji kenormalan data Anderson Darling $(A D)$ menunjukkan bahwa nilai kenormalan data pada kadar air yaitu 0,3 dengan nilai $P$ value yaitu 0,516. Didalam teori statistik, Nilai $P$-value tidak boleh kurang dari 0,05 yang mana jika nilai lebih dari nilai tersebut maka data tergolong data normal atau proses berjalan baik sedangkan jika nilai $P$-value kurang dari 0,05 maka data dikategorikan sebagai data tidak normal atau proses berjalan tidak baik.

\section{Kesimpulan}

\subsection{Kesimpulan}

Berdasarkan hasil penelitian mengenai analisis kualitas briket arang tempurung kelapa dengan variasi bahan perekat tepung kanji dan tepung sagu sebagai bahan bakar alternatif dapat diambil kesimpulan sebagai berikut:

1. Berdasarkan analisis data menggunakan minitab 17 didapatkan bahwa briket arang tempurung kelapa dengan bahan perekat tepung kanji dan tepung sagu telah memenuhi standar (SNI NO. 01/6235/2000) dengan nilai hasil uji kenormalan data Anderson Darling (AD) pada kadar air yaitu 0,3, kadar abu yaitu 0,2 , kadar zat menguap yaitu 0,3 , kadar karbon yaitu 0,3 , kerapatan yaitu 0,2 , laju pembakaran yaitu 0,4 dan kekuatan tekan yaitu 0,2. Sedangkan untuk nilai P-value dari kadar air, kadar abu dan kadar zat menguap masingmasing mempunyai nilai $\mathrm{P}$ yaitu 0,5 , untuk kadar karbon terikat yaitu 0,3, nilai $\mathrm{P}$ untuk kerapatan yaitu 0,7 , untuk laju pembakaran yaitu 0,6 dan kekuatan tekan nilai $\mathrm{P}$ yaitu 0,7 . Masing-masing nilai $\mathrm{P}$ besar dari 0,05 artinya nilai proses baik (capable).

2. Nilai rata-rata kualitas briket arang tempurung kelapa dengan bahan perekat tepung kanji kadar air adalah 3,71\%, nilai rata-rata kadar abu adalah 3,38\%, nilai rata-rata kadar zat menguap adalah 3,68 \%, nilai rata-rata kadar karbon terikat adalah 93,14 \%, nilai rata-rata kerapatan adalah $1,46 \mathrm{~g} / \mathrm{cm}^{3}$, nilai ratarata berat jenis adalah $1,52 \times 10^{-6}$ $\mathrm{Kg} / \mathrm{m}^{2} \cdot \mathrm{s}^{2}$, nilai rata-rata laju pembakaran adalah $0,32 \mathrm{~g} / \mathrm{cm}^{2}$, nilai rata-rata keteguhan tekan yaitu 808 $\mathrm{N} / \mathrm{m}^{2}$. Sedangkan nilai rata-rata kualitas briket arang tempurung kelapa dengan bahan perekat tepung sagu kadar air adalah $3,12 \%$, nilai rata-rata kadar abu adalah 3,25\%, nilai rata-rata kadar zat menguap adalah $3,14 \%$, nilai rata-rata kadar karbon terikat adalah 93,71\%, nilai rata-rata kerapatan adalah 1,64 $\mathrm{g} / \mathrm{cm}^{3}$, nilai rata-rata berat jenis adalah 
$1,52 \times 10^{-6} \mathrm{Kg} / \mathrm{m}^{2} \cdot \mathrm{s}^{2}$, nilai rata-rata laju pembakaran adalah $0,47 \mathrm{~g} / \mathrm{cm}^{2}$, nilai rata-rata keteguhan tekan yaitu 715 $\mathrm{N} / \mathrm{m}^{2}$.

3. Kualitas briket arang tempurung kelapa sangat dipengaruhi oleh bahan perekat yang digunakan. Dalam penelitian penggunaan bahan perekat tepung kanji ternyata memberikan keteguhan tekan yang lebih baik jika dibandingkan dengan tepung sagu sehingga tidak mudah hancur dan mempermudah dalam proses pengemasan sedangkan untuk parameter lainnya seperti kadar air, kadar abu, kadar zat menguap, kadar karbon, kerapatan, berat jenis, dan laju pembakaran bergantung pada perbandingan komposisi yang digunakan. Dalam penelitian ini penggunaan perbandingan komposisi 90:10 menunjukkan kualitas produk yang baik sehingga bisa diterapkan dalam proses produksi.

\subsection{Saran}

Dalam penelitian ini tidak dilakukan pengujian nilai kalori karena keterbatasan alat uji laboratorium. Oleh sebab itu, untuk penelitian selanjutnya sebaiknya ditambahkan pengujian nilai kalori untuk mengetahui seberapa besar nilai kalorinya.

\section{DAFTAR PUSTAKA}

[1] Erwandi. (2005). Sumber Energi Arus: Alternatif Pengganti BBM, Ramah Lingkungan, dan Terbarukan. (Online). (https://www.energi.lipi.go.id. Diakses tanggal 19 Juli 2019)

[2] Himawanto, D. A. (2003). Pengolahan limbah pertanian menjadi biobriket sebagai salah satu bahan bakar alternatif. Surakarta: Universitas Surakarta.

[3] Kurdiawan, Z. Y. dan Erlangga, M. (2012). Pemanfaatan Limbah Sekam Padi Menjadi Briket Sebagai Sumber Energi Alternatif Dengan Proses Karbonisasi Dan Non-Karbonisasi. Wastewater Treatment Lab, Chemical engineering, Institut Teknologi Surabaya.
[4] Kurniawan, A. (2013). Pembuatan Briket Arang dari Campuran Cangkang Bintaro dan Bambu Betung Menggunakan Perekat Amilum. Palembang: Polteknik Negeri Sriwijaya.

[5] Lestari, A. P. dan Tjahjani, S. (2015). Pemanfaatan Bungkil Biji Kapuk (Ceiba Pentandra) Sebagai Campuran Briket Sekam Padi. Department of Chemistry, Faculty of Mathematics and Natural Sciences State University of Surabaya, UNESA Journal of Chemistry Vol. 4, No.1, 69-74.

[6] Machmud, S. (2011). Kajian Ekonomis Industri Briket Arang Tempurung Kelapa. STIE Pasundan Bandung, Jurnal Ekonomi, Bisnis \& Entrepreneurship Vol. 5, No. 1, April 2011, 45-51.

[7] Nurhilal, O dan Suryaningsih, S. (2018). Pengaruh Komposisi Campuran Sabut Dan Tempurung Kelapa Terhadap Nilai Kalor Biobriket Dengan Perekat Molase. Departemen Fisika Fmipa Universitas Padjadjaran, Jurnal Ilmu Dan Inovasi Fisika, Vol. 02, No. 01, 8 $-14$.

[8] Putra, Z. (2013). Analisis karbon aktif arang kayu bakau. Tesis. S2 Ilmu Fisika, Universitas Sumatra Utara.

[9] R. Sudradjat dan Salim S., (1994) "Petunjuk Pembuatan Arang Aktif" Badan Penelitian dan Pengembangan Kehutanan.

[10] Standar Nasional Indonesia. (2000). SNI Briket Arang Kayu SNI 01-6235-2000. Badan Standarisasi Nasional - BSN. (online), (http://sisni.bsn.go.id/index.php/sni_m ain/sni/detail sni/5781. diakses tanggal 20 Januari 2019).

[11] Thoha, Y. M. dan Fajrin, E. D. (2010). Pembuatan Briket Arang Dari Daun Jati Dengan Sagu Aren Sebagai Pengikat. Jurusan Teknik Kimia, Fakultas Teknik, Universitas Sriwijaya, No.1, Vol. 17, Januari 2010.

[12] Vuspayani, R. (2017). Uji Kualitas Fisis Briket Dari Campuran Limbah Bahan Cangkang Biji Jarak Pagar Dengan Tempurung Kelapa, Jurusan Fisika, Fakultas Sains Dan Teknologi Uin Alauddin Makassar 